\title{
Physical, Mechanical, and Biological Properties of Silafluofen-treated Tropical Wood Using Multi-Phase Carbon Dioxide Impregnation
}

\author{
Musrizal Muin
}

\begin{abstract}
A new approach in wood preservative treatment using carbon dioxide $\left(\mathrm{CO}_{2}\right)$ as a carrier solvent has been developed and evaluated its effect on the physical, mechanical, and biological properties of treated tropical wood. It employs $\mathrm{CO}_{2}$ at various combinations of temperatures and pressures in a treatment vessel at once and is called Multi-Phase Carbon Dioxide $\left(\mathrm{MPCO}_{2}\right)$ treatment. Three commercial tropical wood species (Agathis sp., Palaquium sp., and Heritiera sp.) measuring 1.5 $\mathrm{cm}(\mathrm{T}) \times 1.5 \mathrm{~cm}(\mathrm{R}) \times 15 \mathrm{~cm}(\mathrm{~L})$ were prepared for the treatment with a termiticide (silafluofen). A treatment cycle was performed by loading two specimens of each wood species, applying the temperature of $15^{\circ} \mathrm{C}$ and pressure of $60 \mathrm{~kg} / \mathrm{cm}^{2}$, gradually increasing the temperature and pressure, respectively, to $35^{\circ} \mathrm{C}$ and $80 \mathrm{~kg} / \mathrm{cm}^{2}$, and releasing the pressure to atmosphere. The treatment was conducted with five replicates. Untreated and treated specimens were then evaluated their physical, mechanical, and biological properties. Results show that the $\mathrm{MPCO}_{2}$ treatment significantly enhanced the termite resistance of treated wood without any adverse effects on their physical and mechanical properties.
\end{abstract}

Key words: wood preservation, carbon dioxide, carrier solvent, tropical wood, silafluofen.

\section{Introduction}

Since the availability of naturally resistant wood species is now becoming very limited, wood preservation technology plays an important role in ensuring a longer service life for the forest product. Most of the available wood species are currently categorized as low natural durability. In Indonesia, there are about $85.7 \%$ of 4000 s identified wood species belonging to the low durability category (Martawijaya 1996). This condition indicates that without preserving technology, such wood species will be easily attacked by organisms in their uses and therefore cause significant economic losses.

Current commercial wood preserving technologies, especially pressure methods are proved to be effective in enhancing the service life of treated wood. Although these treatment methods definitely contribute to the protection of wood products, they also have some unfavorable side effects such as the need of re-drying process after treatment, causing negative impact to the physical and mechanical properties of the treated wood. Because of the limitation, some novel approaches have become the subject of interest for advanced developments such as vapor treatment and supercritical fluid impregnation (Murphy and Turner 1989; Hashim et al. 1994; 1997; Tsunoda 2001).

The use of supercritical fluid carbon dioxide $\left(\mathrm{SC}-\mathrm{CO}_{2}\right)$ as a carrier solvent has been well accepted for the extraction of particular constituents of substances due to its high availability, low cost, safety (non-toxic) and easiness to obtain the critical conditions of high solubility and diffusion capacity. Its application in wood preservation is also attracting scientific and commercial interest. Previous investigations indicated potential prospects for the application of $\mathrm{SC}-\mathrm{CO}_{2}$ as a carrier solvent of biocide (Morrell et al. 1993; 1997; Acda et al. 1996; 1997). However, the success of the $\mathrm{SC}-\mathrm{CO}_{2}$ treatment still requires further studies, particularly on developing an energy-saving process. The treatment at lower temperatures and pressures are thought to be practical and economically beneficial. This current study was aimed at evaluating physical, mechanical and biological properties of some tropical wood species treated with Silafluofen using carbon dioxide impregnation with a new approach.

\section{Materials and Methods}

\section{Sample Preparation}

Specimens of three tropical timber species (Agathis sp., Palaquium sp., and Heritiera sp.) measuring $15(\mathrm{R}) \times$ $15(T) \times 150(L) \mathrm{mm}$ were used for treatment trials. All specimens were double-coated with epoxy resin on each cut end to simulate the penetration of carbon dioxide through surface areas of practically sized products. All specimens were then conditioned at $60^{\circ} \mathrm{C}$ for $48 \mathrm{~h}$ prior to the treatment.

Silafluofen [(4-ethoxyphenyl) (3-4 (4-fluoro-3phenoxyohenyl) propyl dimethyl silane)] (94.2\% a.i., supplied by Hoechst AG, Germany) was selected as a candidate termiticide because it has been widely used and performed good stability in the environment (Minamite et al. 1990). The termiticide was dissolved in ethanol $(20 \% \mathrm{w} / \mathrm{v}$, p.a. $99.9 \%$, Merc) to be incorporated in impregnation process. The $\mathrm{CO}_{2}(99.5 \%)$ was purchased from PT. Aneka Gas, Makassar. 


\section{Treatment}

The treatment process is newly named as Multi-Phase Carbon Dioxide $\left(\mathrm{MPCO}_{2}\right)$ treatment. For the purpose of the treatment, two specimens of each wood species were placed in the treatment vessel $(60 \mathrm{~mm}$ diameter and 190 $\mathrm{mm}$ high) at a time. The vessel was immersed in a temperature-controlled water bath with the initial temperature of $15^{\circ} \mathrm{C}$. Liquefied $\mathrm{CO}_{2}$ with silafluofen-ethanol solution $(5 \mathrm{ml})$ mixed in a preservative chamber was introduced into the treatment vessel until the pressure in the vessel became equal to that of the $\mathrm{CO}_{2}$ source bomb. The treatment vessel was then preheated up to the $\mathrm{CO}_{2}$ critical temperature $\left(32 \sim 35^{\circ} \mathrm{C}\right)$, causing the increase of the pressure inside the vessel up to the region of $\mathrm{CO}_{2}$ critical pressure $\left(75 \sim 80 \mathrm{~kg} / \mathrm{cm}^{2}\right)$. The pressure and temperature inside the vessel were monitored by a pressure gauge and a thermometer inserted into the vessel at the center. The treatment vessel was maintained under the test conditions for $30 \mathrm{~min}$ to allow $\mathrm{SC}_{-}-\mathrm{CO}_{2}$ with silafluofen to circulate inside the vessel. At the end of the treatment, the pressure was released to ambient atmospheric pressure and the treated materials were recovered for subsequent tests.

\section{Physical and Mechanical Tests}

Physical defects were visually inspected just after treatment. Specimens $[15(\mathrm{R}) \times 7(\mathrm{~T}) \times 150(\mathrm{~L}) \mathrm{mm}]$ were then cut from each original wood specimen for strength test. Specimens of the same size were also prepared from untreated wood. All specimens were preconditioned at room temperature $\left( \pm 25^{\circ} \mathrm{C}\right)$ and $75 \%$ relative humidity for 3 weeks.

Three-point bending tests with a loading speed of 1 $\mathrm{mm} / \mathrm{min}$ were carried out using Universal Testing Machine (INSTRON, England) to determine the modulus of elasticity (MOE) and modulus of rupture (MOR) of the treated and untreated specimens.
Span lengths of $100 \mathrm{~mm}$ were used for the strength tests. The results before and after treatment were compared by Dunnett's test.

\section{Termite Test}

A termite test was conducted according to the Japan Wood Preserving Association (JWPA) standard JWPS-TWP.1 (2001) with modification. Two blocks $(15 \times 15 \times 20 \mathrm{~mm})$ were cut from the original specimens of all untreated and treated wood for the termite test. Five test blocks were randomly selected and individually placed at the center of the plaster bottom of cylindrical test containers $6 \mathrm{~cm}$ in diameter). A total of 150 workers and 15 soldiers of Coptotermes sp. were introduced into each test container. The assembled containers were set on a damp cotton pad and kept at $28 \pm 2^{\circ} \mathrm{C}$ and $98 \%$ relative humidity in the dark for 3 weeks. Termite mortality was recorded weekly, and the percentage mass loss of each test block was calculated at the end of test period. Calculation of the percent mass loss was based on the difference in oven-dried weight before and after the termite test. Test results were compared between untreated and treated materials by Tukey's test.

\section{Results and Discussion}

\section{Physical and Mechanical Properties of Treated Wood}

$\mathrm{MPCO}_{2}$ treatment did not cause any physical defects in the treated wood specimens as shown in Tables 1, 2, and 3 . These data show that moisture content, density, and dimensional stability of wood are not negatively affected by the treatment. The results indicate that there is no negative chemical interaction between $\mathrm{CO}_{2}$ as carrier solvent and the treated wood. These findings are in consistent with the results of previous studies (Larsen et al. 1992; Muin and Tsunoda 2003). Similar effects were also found on the mechanical properties of the treated materials as presented in Tables 4 and 5.

Table 1. Moisture content and density of wood before and after treatment using Multi-Phase Carbon Dioxide (MPCO 2$)$ impregnation*.

\begin{tabular}{lcccc}
\hline Wood Species & \multicolumn{2}{c}{ Moisture Content $(\%)$} & \multicolumn{2}{c}{ Density $\left(\mathrm{g} / \mathrm{cm}^{3}\right)$} \\
\cline { 2 - 5 } & Untreated & Treated & Untreated & Treated \\
\hline Agathis sp. & $14.26 \pm 0.387$ & $13.82 \pm 0.009$ & $0.49 \pm 0.05$ & $0.51 \pm 0.06$ \\
Palaquium sp. & $12.90 \pm 0.004$ & $13.12 \pm 0.003$ & $0.42 \pm 0.06$ & $0.45 \pm 0.05$ \\
Heritiera sp. & $13.52 \pm 0.004$ & $13.33 \pm 0.007$ & $0.62 \pm 0.07$ & $0.60 \pm 0.08$ \\
\hline
\end{tabular}

${ }^{*}$ Mean and standard deviation of ten replicates.

Table 2. Volumetric shrinkage and swelling of wood before and after treatment using Multi-Phase Carbon Dioxide $\left(\mathrm{MPCO}_{2}\right)$ impregnation*.

\begin{tabular}{lcccc}
\hline \multirow{2}{*}{ Wood Species } & \multicolumn{2}{c}{ Shrinkage (\%) } & \multicolumn{2}{c}{ Swelling (\%) } \\
\cline { 2 - 5 } & Untreated & Treated & Untreated & Treated \\
\hline Agathis sp. & $6.22 \pm 0.03$ & $5.90 \pm 0.04$ & $5.19 \pm 0.01$ & $6.38 \pm 0.04$ \\
Palaquium sp. & $4.60 \pm 0.01$ & $5.00 \pm 0.01$ & $5.32 \pm 0.03$ & $4.80 \pm 0.01$ \\
Heritiera sp. & $6.58 \pm 0.01$ & $6.68 \pm 0.01$ & $6.07 \pm 0.01$ & $6.34 \pm 0.01$ \\
\hline
\end{tabular}

${ }^{*}$ Mean and standard deviation of ten replicates. 
Table 3. T/R Ratio of wood before and after treatment using Multi-Phase Carbon Dioxide $\left(\mathrm{MPCO}_{2}\right)$ impregnation*.

\begin{tabular}{lcc}
\hline Wood Species & \multicolumn{3}{c}{ T/R Ratio (\%) } \\
\cline { 2 - 3 } & Untreated & Treated \\
\hline Agathis sp. & $1.56 \pm 0.82$ & $1.37 \pm 0.70$ \\
Palaquium sp. & $2.13 \pm 1.37$ & $1.82 \pm 0.88$ \\
Heritiera sp. & $1.37 \pm 0.51$ & $1.36 \pm 0.38$ \\
\hline
\end{tabular}

${ }^{*}$ Mean and standard deviation of ten replicates.

Table 4. Modulus of elasticity (MOE) of wood before and after treatment using Multi-Phase Carbon Dioxide $\left(\mathrm{MPCO}_{2}\right)$ impregnation*.

\begin{tabular}{lcc}
\hline Wood Species & \multicolumn{2}{c}{ MOE $\left(\mathrm{kg} / \mathrm{mm}^{2}\right)$} \\
\cline { 2 - 3 } & Untreated & Treated \\
\hline Agathis sp. & $740.31 \pm 110.83$ & $1074.28 \pm 112.42^{* *}$ \\
Palaquium sp. & $675.69 \pm 91.42$ & $789.13 \pm 35.75^{* *}$ \\
Heritiera sp. & $1153.17 \pm 212.98$ & $966.51 \pm 163.62$ \\
\hline
\end{tabular}

* Mean and standard deviation of ten replicates.

${ }^{* *}$ Statistically significant difference after treatment by Dunnett's test $(\alpha=0.01)$.

Table 5. Modulus of rupture (MOR) of wood before and after treatment using Multi-Phase Carbon Dioxide $\left(\mathrm{MPCO}_{2}\right)$ impregnation*.

\begin{tabular}{lcc}
\hline \multirow{2}{*}{ Wood Species } & \multicolumn{2}{c}{$\mathrm{MOR}\left(\mathrm{kg} / \mathrm{mm}^{2}\right)$} \\
\cline { 2 - 3 } & Untreated & Treated \\
\hline Agathis sp. & $7.37 \pm 0.82$ & $9.63 \pm 1.31^{\star *}$ \\
Palaquium sp. & $6.55 \pm 0.77$ & $8.06 \pm 0.36^{\star *}$ \\
Heritiera sp. & $11.69 \pm 2.11$ & $9.77 \pm 1.51$ \\
\hline
\end{tabular}

${ }^{*}$ Mean and standard deviation of ten replicates.

** Statistically significant difference after treatment by Dunnett's test $(\alpha=0.01)$.

Table 6. Percent mass loss of untreated and silafluofen $\mathrm{MPCO}_{2}$ treated wood.

\begin{tabular}{lccc}
\hline \multicolumn{1}{c}{ Treatment } & \multicolumn{3}{c}{ Mass loss (\%) for each wood species* } \\
\cline { 2 - 4 } & Agathis sp. & Palaquium sp. & Heritiera sp \\
\hline Untreated & $14.40 \pm 3.58 \mathrm{a}$ & $9.34 \pm 5.26 \mathrm{a}$ & $6.10 \pm 1.14 \mathrm{a}$ \\
Silafluofen $\mathrm{MPCO}_{2}$ treated & $0.57 \pm 0.59 \mathrm{~b}$ & $1.03 \pm 0.36 \mathrm{~b}$ & $0.64 \pm 0.39 \mathrm{~b}$ \\
\hline * Mean and standard deviation of five specimens. Values in column with different letters are significantly diffferent by Tukey's \\
test $(\mathrm{a}=0.01)$.
\end{tabular}

Table 4 shows that $\mathrm{MPCO}_{2}$ treatment with the incorporation of silafluofen had no detrimental effect on the MOE of the treated wood species. A similar result was also found for the effect of the treatment on the MOR of treated wood (Table 5). Moreover, in the cases of Agathis and Palaquium species, the $\mathrm{MPCO}_{2}$ treatment resulted in increased MOE and MOR of the treated specimens. On the other hand, the decreased MOE and MOR of treated Heritiera species due to the preservative treatment were not statistically significant. The results indicate that the physical interaction between wood samples and $\mathrm{CO}_{2}$ during $\mathrm{MPCO}_{2}$ impregnation may occur and contribute to the changes in the strength properties.

\section{Termiticidal Properties of Treated Wood}

The $\mathrm{MPCO}_{2}$ treatment with the incorporation of silafluofen as a termiticide significantly improved the termite resistance of all treated wood species, as shown by termite mortality and wood mass loss. The exposures of all treated materials for termite test was always accompanied by $100 \%$ termite mortality only after less than five days, while those of untreated specimens showed the termite mortality of less than $20 \%$ after 21 days. In addition, mass loss data indicated that the $\mathrm{MPCO}_{2}$ treatment gave a good protection to termite attacks for all treated wood species (Table 6). It is much more obvious when all specimens were observed for their damage because of termites. Untreated specimens clearly showed visual damage due to the termite attacks, while treated specimens did not show similar damage. This condition indicated that the values of mass losses found in the treated specimens were not due to the termite attacks, but it was mostly because of the material handling during testing and cleaning processes. Results on the termitite test suggest that the $\mathrm{MPCO}_{2}$ impregnation was able to transport a sufficient amount of silafluofen into the wood for protection against termite attack. 


\section{Conclusions}

Wood preservation using Multi-Phase Carbon Dioxide $\left(\mathrm{MPCO}_{2}\right)$ treatment significantly improved the termite resistance of tropical wood species such as Agathis sp., Palaquium sp., and Heritiera sp. The treatment method had no detrimental effects on the physical and mechanical properties of the treated tropical wood species. Moreover, in some cases, the $\mathrm{MPCO}_{2}$ treatment resulted in increased physical and mechanical properties of the treated tropical wood.

\section{References}

Acda, M.N.; J.J. Morrell; K.L. Levien. 1996. Decay Resistance of Composites following Supercritical Fluid Impregnation with Tebuconazole. Material und Organismen 30(4): 293-300.

Acda, M.N.; J.J. Morrell; K.L. Levien. 1997. Effects of Supercritical Fluid Treatments on Physical Properties of Wood-based Composites. Wood and Fiber Science 29(2): 121-130.

Hashim, R.; R.J. Murphy; D.J. Dickinson; J.M. Dinwoodie. 1994. The Mechanical Properties of Boards Treated with Vapor Boron. Forest Products Journal 44(10): 7379.

Hashim, R.; R.J. Murphy; D.J. Dickinson; J.M. Dinwoodie. 1997. The Physical Properties of Boards Treated with Vapor Boron. Forest Products Journal 47(1): 61-66.

JWPS-TW-P.1. 2001. Laboratory Test Method to Evaluate Effectiveness of Termiticides for Pressure Treatment and Performance Requirements of the Treated Materials. Japan Wood Preserving Association.

Larsen, A.; N.A. Jentoft; T. Geibokk. 1992. Extraction of Formadehyde from Particelboard with Supercritical Carbon Dioxida. Forest Products Journal 42(4): 45-48.
Martawijaya, A. 1996. Keawetan Kayu dan Faktor yang Mempengaruhinya. Petunjuk Teknis. Pusat Penelitian dan Pengembangan Hasil Hutan dan Sosial Ekonomi Kehutanan. Bogor.

Minamite, Y.; T. Kanzaki; Y. Katsuda. 1990. Application of A Novel Silaneophane (Hoe-498) to Termiticides. Japan Journal of Environmental Entomology and Zoology 2: 177-122.

Morrell, J.J.; K.L. Levien; E.S. Demessie; S. Kumar; S. Smith; H.M. Barnes. 1993. Treatment of Wood using Supercritical Fluid Processes. Proceedings of Canadian Wood Preservers Association 14: 6-25.

Morrell, J.J.; K.L. Levien; E.S. Demessie; M.N. Acda. 1997. Impregnating Wood with Biocides Using Supercritical Carbon Dioxide: Process Parameters, Performance and Effects on Wood Properties. Proceedings of American-Wood Preservers Association 93: 367-384.

Muin, M.; K. Tsunoda. 2003. Preservative Treatment of Wood-Based Composites with 3-Iodo-Propynyl Butylcarbamate Using Supercritical Carbon Dioxide. Impregnation. Journal of Wood Science 49: 430-436

Murphy, R.J.; P. Turner. 1989. A Vapor Phase Preservative Treatment of Manufactured Wood-based Materials. Wood Science and Technology 23: 273-279.

Tsunoda, K. 2001. Preservative Properties of Vapor-borontreated Wood and Wood-based Composites. Journal of Wood Science 47(2): 149-53.

\footnotetext{
Musrizal Muin

Forest Products Utilization and Processing Laboratory

Forestry Faculty of Hasanuddin University

JI. Perintis Kemerdekaan, KM 10, Makassar 90245

Tel./Fax. : +62-411-589592

E-mail : musrizal@unhas.ac.id
} 